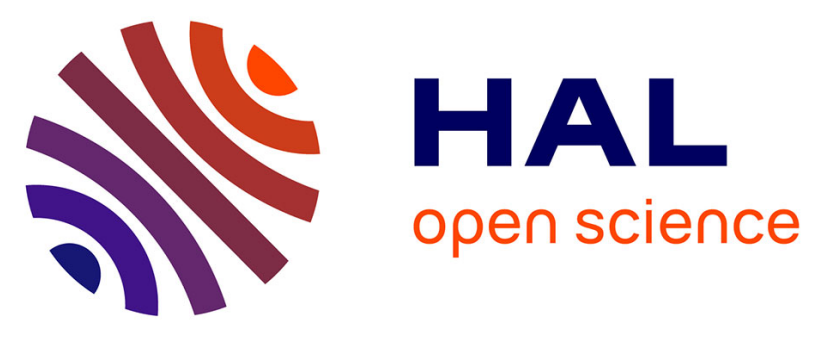

\title{
Experimental conditions and environment effects on thermal fatigue damage accumulation and life of die-casting steel X38CrMoV5 (AISI H11)
}

Farid Medjedoub, Gilles Dour, Sabine Le Roux, Pascal Lamesle, Mehdi Salem, Patrick Hairy, Farhad Rezai-Aria

\section{To cite this version:}

Farid Medjedoub, Gilles Dour, Sabine Le Roux, Pascal Lamesle, Mehdi Salem, et al.. Experimental conditions and environment effects on thermal fatigue damage accumulation and life of die-casting steel X38CrMoV5 (AISI H11). International Journal of Microstructure and Materials Properties, 2008, 3 (2/3), pp.336-349. 10.1504/IJMMP.2008.018739 . hal-01685075

\section{HAL Id: hal-01685075 \\ https://imt-mines-albi.hal.science/hal-01685075}

Submitted on 15 Feb 2019

HAL is a multi-disciplinary open access archive for the deposit and dissemination of scientific research documents, whether they are published or not. The documents may come from teaching and research institutions in France or abroad, or from public or private research centers.
L'archive ouverte pluridisciplinaire HAL, est destinée au dépôt et à la diffusion de documents scientifiques de niveau recherche, publiés ou non, émanant des établissements d'enseignement et de recherche français ou étrangers, des laboratoires publics ou privés. 


\title{
Experimental conditions and environment effects on thermal fatigue damage accumulation and life of die-casting steel X38CrMoV5 (AISI H11)
}

\section{Farid Medjedoub}

Previously with CTIF and Ecole des Mines d'Albi-Carmaux, France

Now with Renault Sport, France

E-mail: farid.medjedoub-renexter@ renault.com

\section{Gilles Dour, Sabine Le Roux, Pascal Lamesle and Mehdi Salem}

Tools Surface Investigations Unit CROMeP, Ecole Mines Albi, Toulouse University, France

E-mail: dourdour@enstimac.fr

E-mail: leroux@enstimac.fr

E-mail: pascal.lamesle@enstimac.fr

E-mail: mehdi.salem@enstimac.fr

\section{Patrick Hairy}

R\&D and Process Optimisation

CTIF, French Technical Centre of Foundry, France

E-mail: hairy@ctif.com

\section{Farhad Rézaï-Aria*}

Tools Surface Investigations Unit

CROMeP, Ecole Mines Albi, Toulouse University, France

E-mail: rezai@enstimac.fr

*Corresponding author

\begin{abstract}
Thermal Fatigue (TF) is a life-limiting factor in die-casting dies. The effect of the maximum temperature of thermal cycle, $\mathrm{T}_{\max }$, and the heating (or heat flux density) of thermal fatigue (X38CrMoV5 AISI H11) at $47 \mathrm{HRC}$ is investigated. Two microscopic and macroscopic heat-checking cells are identified. The microscopic heat checking is limited to the double-layer oxide scales formed on the external surface of TF specimens. An engineering Paris-type law using $\mathrm{K}_{\max }$, can describe TF surface crack propagation of all tests examined. TF life based on $\sigma_{\max }$ is used to rationalise TF micro- and macroscopic cracking.
\end{abstract}

Keywords: Thermal Fatigue; TF; crack and initiation; chromium steels; fatigue-oxidation interaction fatigue. 


\section{Introduction}

Thermal Fatigue (TF) causes gradual deterioration and eventual cracking of materials by alternate heating and cooling during which free thermal expansion/contraction is partially or completely constrained (Rézaï-Aria, 2002). Hot-forming tools work under transient thermal cycling and so are prone to TF crack initiation and propagation (as in rolling (Da Silva and Boccalini, 2005), forging, die casting, etc.). TF is a life-limiting factor in die-casting dies, in particular high-pressure die casting. TF damage may be activated and/or coupled with environment effects such as oxidation and corrosion (see Figure 1). Surface heat-checking that forms under multiaxial loading is the typical damage network observed in die-casting and hot-working tools. The temperature distribution in a die changes from one region to another (Medjedoub et al., 2005). The crack initiation and propagation is controlled by the actual stress and thermal conditions, as well as by environmental effects. It is therefore important to know about the industrial thermal cycle characteristics. This contribution deals with the investigations of heat-checking under various thermal fatigue conditions. The heat-checking mechanisms and oxidation effects are discussed. Thermal fatigue crack propagation and life are reported.

Figure 1 A cross-sectioned view of typical cracking of high-pressure Al die-casting die surfaces hat are damaged by the surface heat-checking

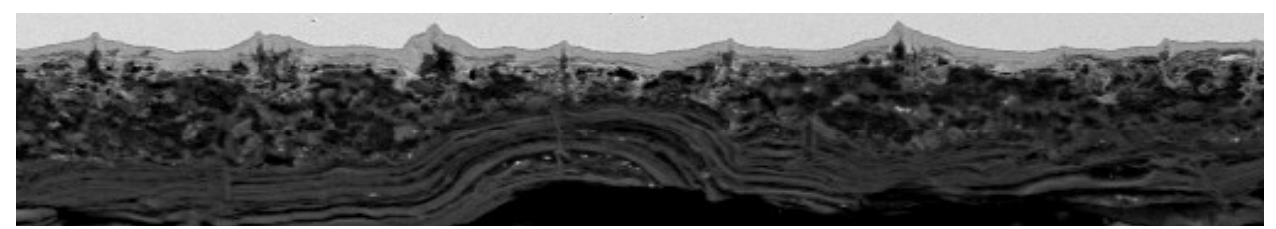

Note: Note wedged-type cracks that are initiated and propagated towards the tool's bulk.

Source: Rézaï-Aria et al. (2006)

\section{Experiments and materials}

\subsection{Materials}

A double-tempered martensitic steel X38CrMoV5 (AISI H11) with 47HRC (mostly) was investigated. Forged bars were purchased from Aubert and Duval France and double heat-treated using Balzers (Balitherme structure). TF specimens were then machined from the heat-treated bars.

Table 1 Chemical composition of X38CrMoV5 (AISI H11, wt\%)

\begin{tabular}{lcccccccc}
\hline$C$ & $C r$ & $M o$ & $V$ & $S i$ & $M n$ & $S$ & $P$ & $F e$ \\
\hline 0.396 & 5.05 & 1.25 & 0.47 & 0.94 & 0.36 & $<0.003$ & 0.009 & Bal \\
\hline
\end{tabular}

\subsection{Thermal fatigue reference cycle and test conditions}

Recently a special well-designed heat flux gauge (sensor) using a Sapphir fibre and several well-placed thermocouples with small diameters was developed to measure the heat flux density transferred during casting from the surface to the die (Dour et al., 2005a; 2006) (see Figure 2). The temperature at the surface of the die is calculated via 
normalisation and a numerical inverse method by proceeding with a careful calibration of the pyrometer connected to the optical Sapphir fibre for determination of the emissivity of the molten Al-alloy as well as the entire data acquisition chain response, the position of thermocouples in the gauge and also a careful placement of the sensor in the die considering the critical position in a die. As an example, the variation of the calculated temperature via the sensor and estimated thermoelastic stress versus time is reported (see Figure 2).

Figure 2 Heat flux density gauge placed in HPDCs (a) and calculated temperature and thermoelastic stress versus time (b)

(a)
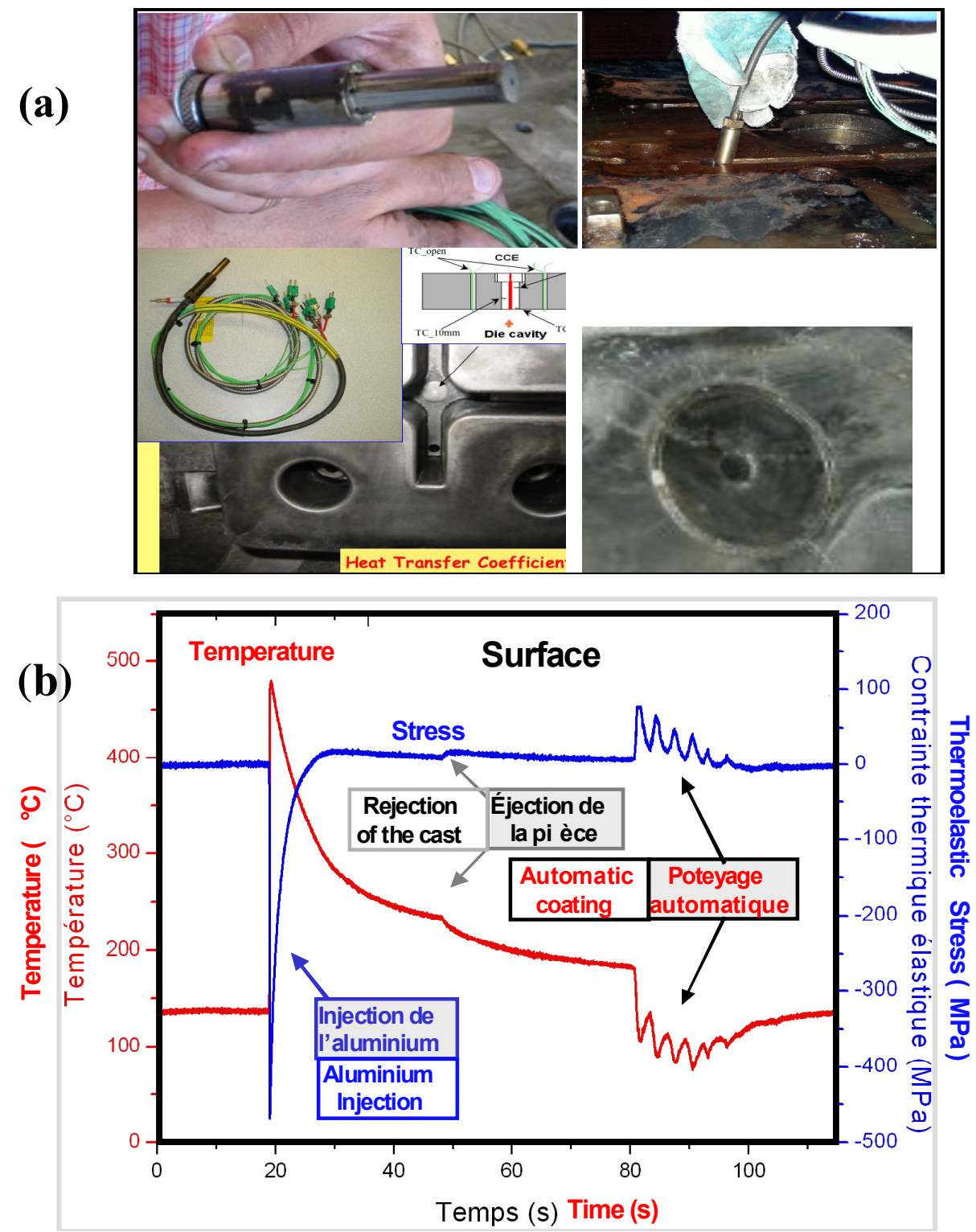
Details of TF and an in-house lab view data acquisition system using induction heating (25 kW, 100 to $400 \mathrm{kHz}$ ) are given in Jean et al. (1999) and Medjedoub (2004). Tubular specimens (10 mm wall thickness) with no external air forcing and an internal continuous water-cooling are employed (see Figure 3). The external surface is polished. Based on several heat flux measurements on HPDC dies, a typical 'reference thermal fatigue cycle' is used. A dummy specimen was first carefully instrumented by at least five K-type thermocouples spot-welded on the external surface $(0.1 \mathrm{~mm}$ wire's diameter $)$, and eight thermocouples brazed in drilled holds along the longitudinal direction, z-axis $(0.2 \mathrm{~mm}$ wires diameter). The measured temperature-time cycles, T-t, were then used to optimise numerical thermal analysis down under ABAQUS.

Figure 3 Thermal fatigue tubular specimen

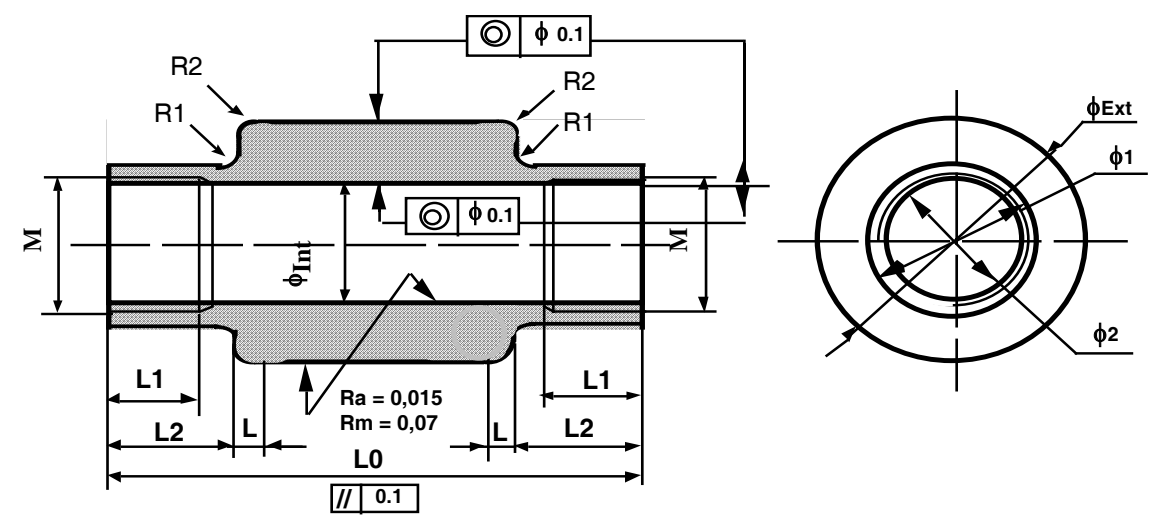

\begin{tabular}{|c|c|c|c|c|c|c|c|c|c|c|}
\hline $\mathrm{L} 0 \pm 0.05$ & $\mathrm{~L} 1_{-0}^{+ \text {pas } 1.75}$ & $\mathrm{~L} 2 \pm 0.05$ & $\mathrm{~L}$ & $\mathrm{R} 1$ & $\mathrm{R} 2$ & $\phi \mathrm{Ext} \pm 0.05$ & $\phi 1 \pm 0.05$ & $\phi 2 \pm 0.05$ & $\phi_{\text {Int } \pm 0.05}$ & $\mathrm{M}$ \\
\hline 80 & 18 & 20 & 5 & 2 & 2 & 30 & 18 & 10 & 10 & $12 \times 1.75$ \\
\hline
\end{tabular}

The minimum temperature at the external surface $\left(\mathrm{T}_{\min }\right)$ is set at $100^{\circ} \mathrm{C}$. Two series of TF experiments are performed with: 1$)$ four heating periods $(1.2,2,3.7$, and $6.5 \mathrm{~s})$ to achieve $\left.\mathrm{T}_{\text {max }}=650^{\circ} \mathrm{C}, 2\right)$ five $\mathrm{T}_{\max }\left(500^{\circ} \mathrm{C}, 550^{\circ} \mathrm{C}, 600^{\circ} \mathrm{C}, 650^{\circ} \mathrm{C}\right.$ and $\left.685^{\circ} \mathrm{C}\right)$ with the same heating period (about $1 \mathrm{~s}$ ). To achieve such conditions, a constant energy is put on the external surface of specimen. The resulting heat flux density is then estimated by an inverse method well described in Dour et al. (2005a) (see Dour et al., 2006 in this journal). A constant prescribed nominal 'induction power' is therefore input on the external surface of TF specimens for heating. The temperature is continuously recorded via a thermocouple-K spot-welded on the middle part of specimens. This part of specimens is used for monitoring the experiments. The temperature-time cycle measured is used for eventual minor readjustments of induction power while testing. The opposite part of this region is used for optical and SEM observations.

Tests were regularly interrupted to examine systematically the formation and evolution of both micro- and macroscopic heat checking patterns (or cell forming) on prescribed regions. The morphology characteristics of cells (density, mean diameter, etc.) were calculated by image analysis of SEM-constructed cartographies. 


\section{Results and discussions}

\subsection{Thermal and mechanical analysis}

Thermoelastoplastic strains and stresses were calculated by ABAQUS using axisymmetric DCAX4 and CAX4 elements for thermal and mechanical numerical analyses, respectively (Medjedoub, 2004). As boundary conditions in thermal analysis, several heat flux densities $\mathrm{Q}$ and a constant heat transfer coefficient were imposed to external (subdivided in several strips) and internal surface nodes, respectively. The heat flux densities were estimated by 1D analytical calculations (Medjedoub, 2004; Dour et al., 2005b). The measured (see Figure 4a) and calculated temperature-time cycles were compared. Then $\mathrm{Q}$ was adjusted (Medjedoub, 2004) for each region to minimise the difference between the estimated and the measured temperatures. A difference less than $7 \%$ was achieved for all TF experiments. For FEM thermomechanical numerical analysis, tensile curves measured at prescribed temperatures ranging from RT to $700^{\circ} \mathrm{C}$ were used according to ABAQUS software requirements for isotropic hardening constitutive calculations. As an example, a mechanical total strain-temperature loop calculated for a selected element located in the centre of the TF specimen is reported in Figure 4(b).

Figure 4 Measured surface temperature time cycle: (a) at various heating period (or heat flux density) $\mathrm{T}_{\max }=650^{\circ} \mathrm{C}$ and (b) a typical calculated stress-mechanical strain hysteresis loop by numerical simulations
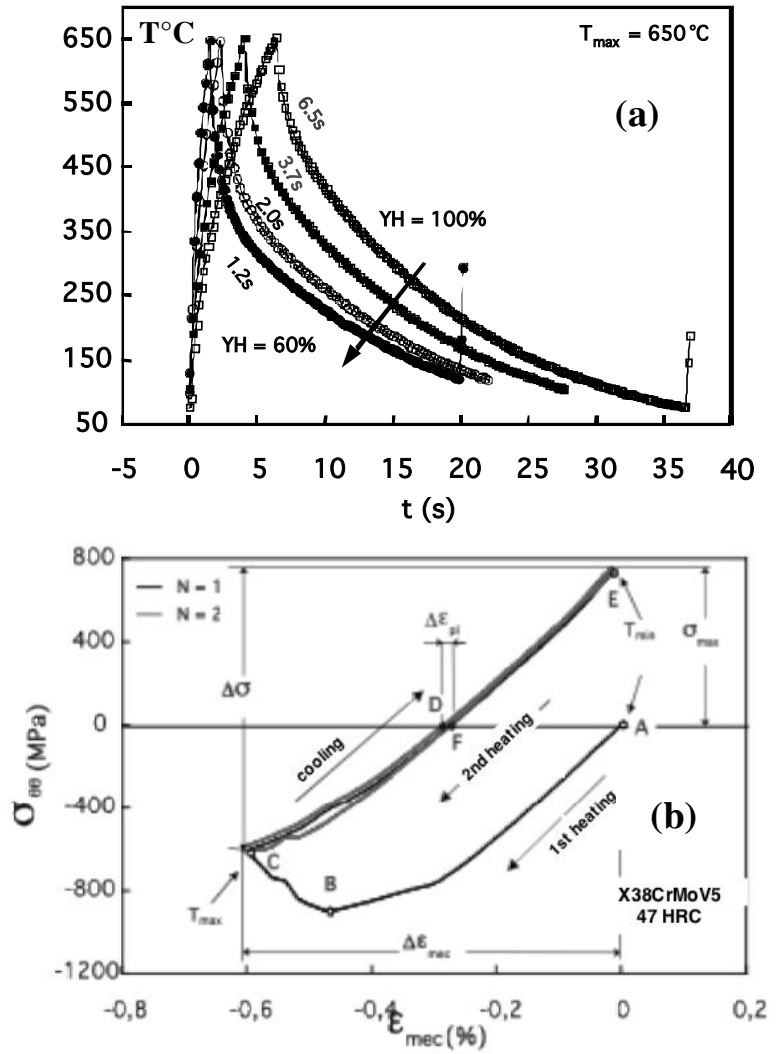
As can be observed, this element is put under an extended compressive strain in first heating. Then the element is put under tension during cooling. The maximum stress $\sigma_{\max }$ is achieved at $T_{\min }$. The $\sigma_{\min }$ during the first heating is achieved at an intermediate temperature between $T_{\min }$ and $T_{\max }$. The first cycle produces maximum plastic strain amplitude defined as the difference between strain at point $\mathrm{A}$ and point $\mathrm{D}$ in the first hysteresis loop. This is a typical stress-strain behaviour in the thermal fatigue of metallic materials. During the second heating and cooling cycle, the plastic strain becomes very much less. In addition, contrary to the first cycle, $\sigma_{\min }$ is achieved at $T_{\max }$. This is one of the reasons why several fully stop/restarting operations in hot forming (for example, for changing or repairing of tool) do more damage to a tool experiencing transient temperature conditions compared to a non-stop working operating condition. The thermo-elasto-viscoplatic analyses show that $\sigma_{\min }$ and $\sigma_{\max }$ can evolve (Ahmer et al., 2006). However, as the plastic strain of concern is small, an elasto-plastic calculation can be relevant to the damage analysis and life modelling (Daffos, 2004; Oudin et al., 2001).

\subsection{Damage mechanisms: oxidation, micro- and macroscopic TF cracking}

While the oxide morphology depends upon $\mathrm{T}_{\max }$, the oxide scale always consists of tow layers, one rich in $\mathrm{Cr}$ beneath the steel and one poor in $\mathrm{Cr}$ in direct contact with air that has quasi-identical thickness (see Figure 5). The TF oxidation kinetic seems to obey a classical parabolic law (doxide $=\mathrm{K} . \sqrt{\mathrm{t}}$ ) (Medjedoub et al., 2008; Medjedoub, 2004). The same kinetics is also observed in isothermal LCF (Daffos, 2004) and non-isothermal (thermomechanical) fatigue (Oudin et al., 2001). Both oxide-scales are cracked by 'heat-checking'. Such damage mechanism is named 'microscopic heat-checking' considering the depthsof short cracks that are comparable to the thickness of both oxide scales (see Figure 5). Macro cracks propagate inward base steel from the short crack tips forming the micro heat-checking cells. By the coalescing of isolated cracks and recracking of already existent cracks, a network of interconnected macro cracks, named 'macroscopic-cell' or 'macroscopic heat-checking' form (see Figure 5). Figure 6 shows that the heat-checking (density) is $\mathrm{T}_{\max }$ and/or $\Delta \mathrm{T}\left(=\mathrm{T}_{\max }-100^{\circ} \mathrm{C}\right)$ independent while it is heating-rate (or heat flux density)-dependent when $\Delta \mathrm{T}$ is constant $\left(\mathrm{T}_{\max }=650^{\circ} \mathrm{C}\right)$.

Figure 5 The role of the oxidation on the formation of the micro- and macroscopic heat-checking thermal fatigue cracking

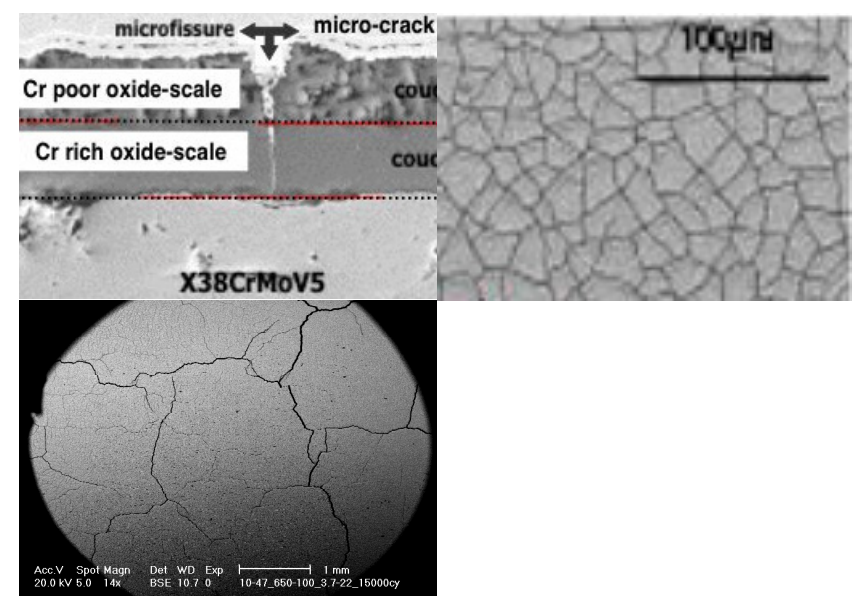


Figure 6 Effect of $\mathrm{T}_{\max }$ and heating period (or heat flux density, $\mathrm{T}_{\max }=650^{\circ} \mathrm{C}$ ) on the microscopic heat-checking aspect
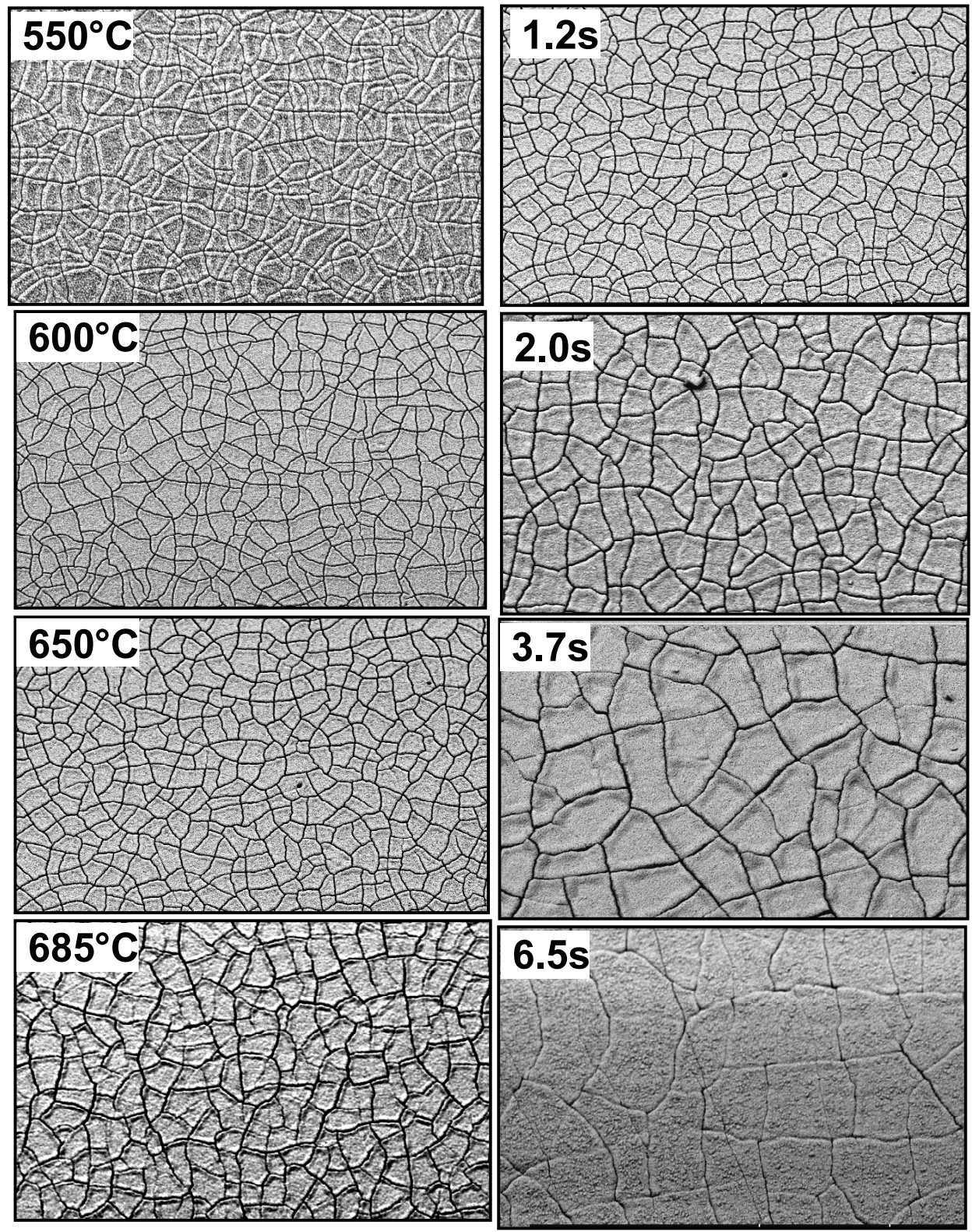

Crack tip SEM observations have shown that macro crack propagation is also dominated by stress state (uni- or multiaxial loading). These observations indicate that cracks advance step by step by zigzagging between longitudinal and circumferential directions where two principal stresses are prevailing. Further and more detailed investigations are, however, required to get better insight in such $\mathrm{TF}$ crack propagation mechanism. Morphology characteristics of the microscopic heat-checking (density, size, mean crack 
length, etc.) are systematically quantified and analysed by an in-house powerful image analyse procedure using the commercial Aphelion software (version 3.1) (Le Roux et al., 2006; Medjedoub, 2004). The cartography of selected regions is constructed by assembling nine SEM images taken from a surface (area $0.8 * 1 \mathrm{~mm} * \mathrm{~mm}$ ). The procedure has several steps: the median filtering to reduce the noise in the grey scale image, the contrast enhancement, thresholding routine to detect darken micro cracks and binarisation of the image to finally obtain a network of closed skeletonised cells that is convenient for relevant quantification and image analysis (Medjedoub, 2004).

Figure 7 presents the variation of heat-checking density $\rho$ as a function of the number of TF cycles for all experiments. The heat-checking network forms very early and revolves drastically according to a sigmoïdal trend to achieve a quasi-asymptotic limit that remains unchanged with further TF cycles (Medjedoub, 2004). This asymptotic limit is called the stabilised, or saturated heat checking cell density ( $\rho$ stab).

Figure 7 Evolution of the microscopic heat-checking cell's density as a function of the number of TF cycles
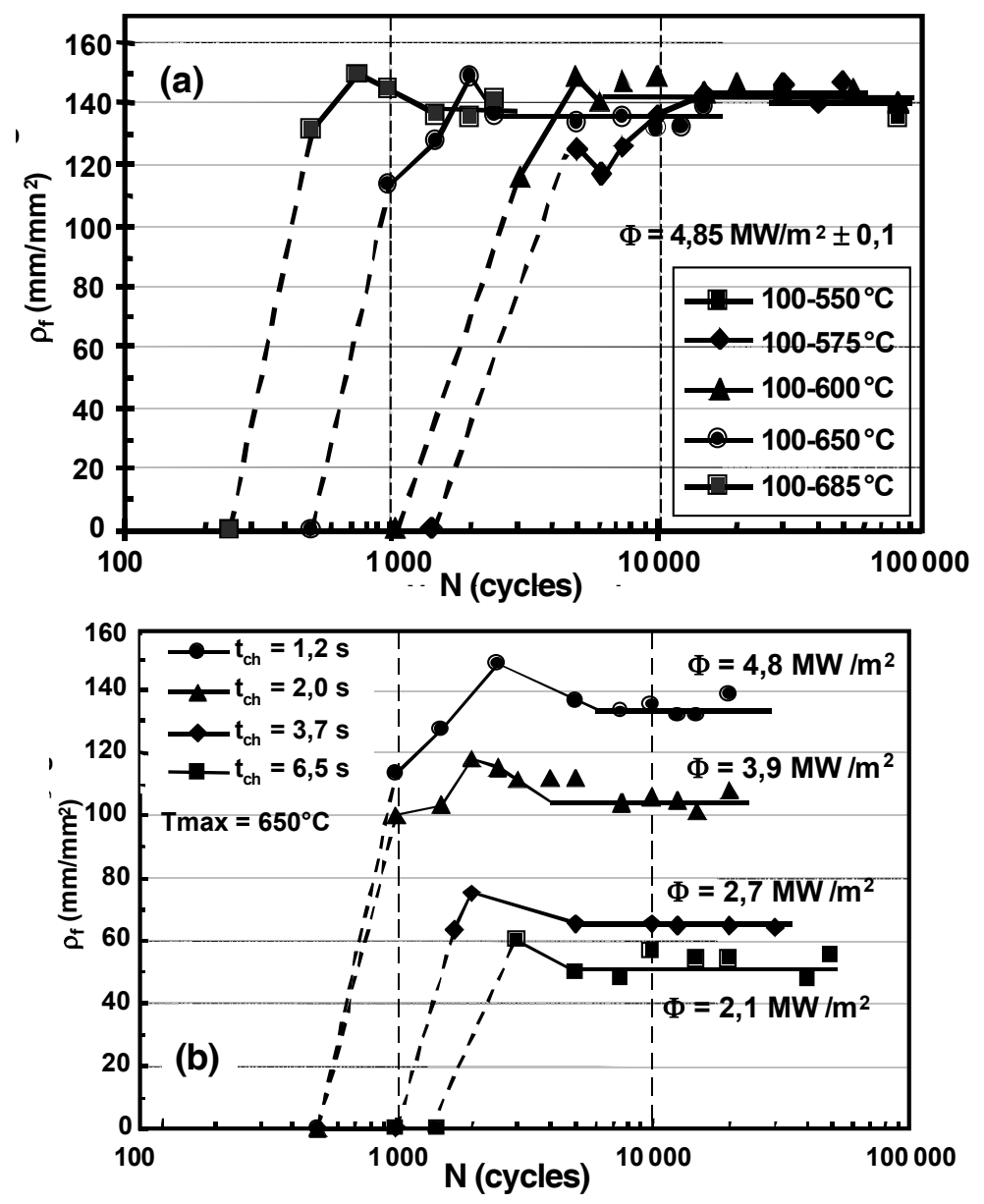

Notes: $\quad$ Effect of: (a) $\mathrm{T}_{\max }$, and (b) heat flux density $(\Phi)$ and/or heating period (tch). 
The number of cycles required to achieve $\rho$ stab is named Nstab. The variation of $\rho$ stab as a function of $\phi$ presents a quasi-linear trend (see Figure 8). By increasing the heat flux density, $\rho$ stab increases. It should be emphasised that $\rho$ stab might presumably achieve a certain limit for much higher $\Phi$. However, owing to limitations of our TF rig facility, such heat-checking morphology characteristics were not assessed.

Figure 8 Variations of stabilised microscopic heat-checking density, $\rho$ stab as a function of the heat flux density $\Phi$ for all TF conditions examined

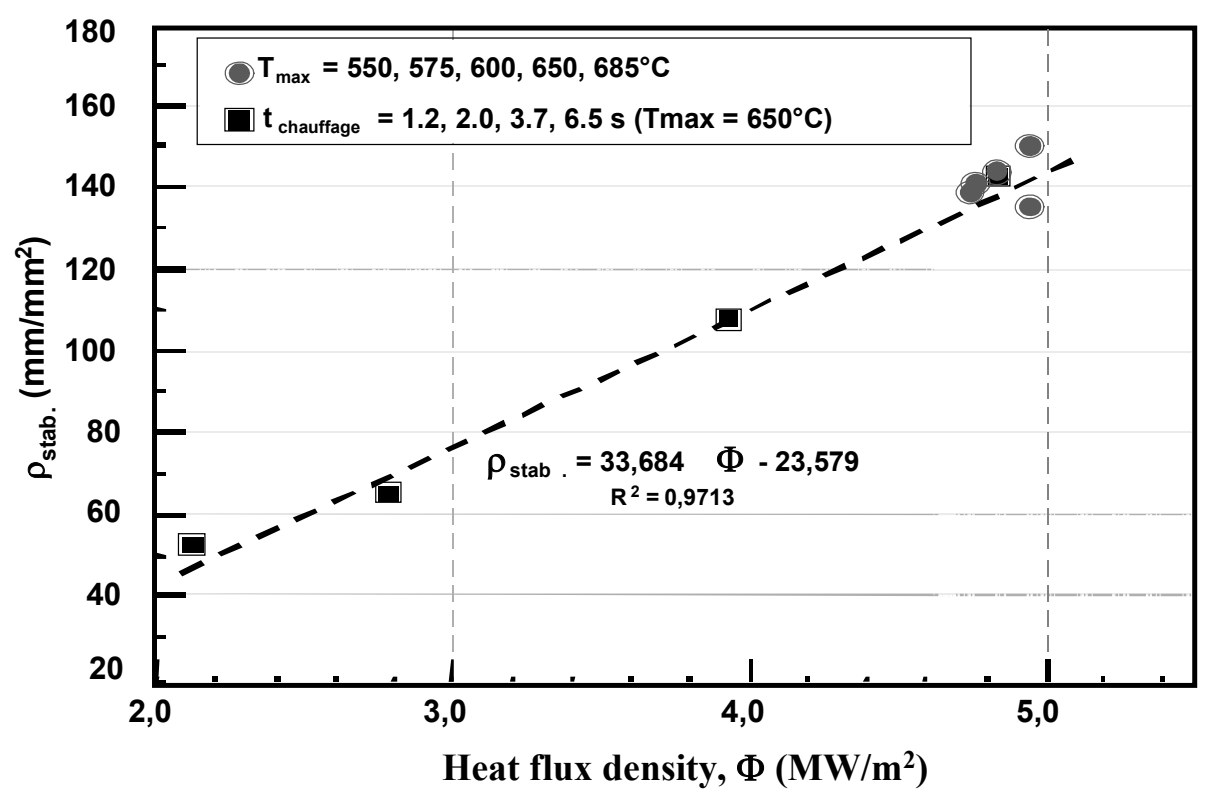

The number of cycles for the micro heat-checking initiation $(\mathrm{Na})$ is an arithmetic value between the cycle when the heat-checking is first detected (N2) and the last previous TF test interruption $(\mathrm{N} 1): \mathrm{Na}=(\mathrm{N} 1+\mathrm{N} 2) / 2$. The precision of $\mathrm{Na}$ depends principally on intervals of test interruptions. In major experiments, tests were interrupted at each $500 \mathrm{TF}$ cycle prior to cells formation thus giving a relatively high accuracy to $\mathrm{Na}$.

\subsection{Thermal fatigue crack propagation}

Several destructive experiments are required to establish an in-depth crack propagation curves (Medjedoub, 2004). We have measured the mean and maximum crack depths. When cracks are short (less than few millimetres), the mean and/or maximum crack length could reasonably be determined with acceptable statistical estimations. As only few cracks propagate inward, sometimes shorter crack depths could be obtained with a higher number of TF cycles, which is irrelevant. Thermal stresses decrease from the external surface and therefore long cracks tend to stop, making it difficult to achieve the reliable in-depth crack versus the number of cycle curves.

The maximum and the mean surface crack lengths were determined on a circumferential strip of $20 \mathrm{~mm}$ width in the centre of specimens (see Figure 9). No macroscopic cracking could be identified with $\mathrm{T}_{\max }$ lower then $600^{\circ} \mathrm{C}$. With increasing 
$\mathrm{T}_{\max }$, the crack propagation rate increases. Under a prescribed $\mathrm{TF}$ condition $\left(\mathrm{T}_{\max }\right.$ and $\mathrm{T}_{\min }$ ), the crack propagation curve is heating period-dependent. In fact, by reducing the heating period, the heat flux density input to the external surface increases, leading to enhance the thermal stresses and consequently the crack propagation rate.

Figure 9 Evolution of the surface mean crack length as a function cycle for different thermal fatigue test conditions
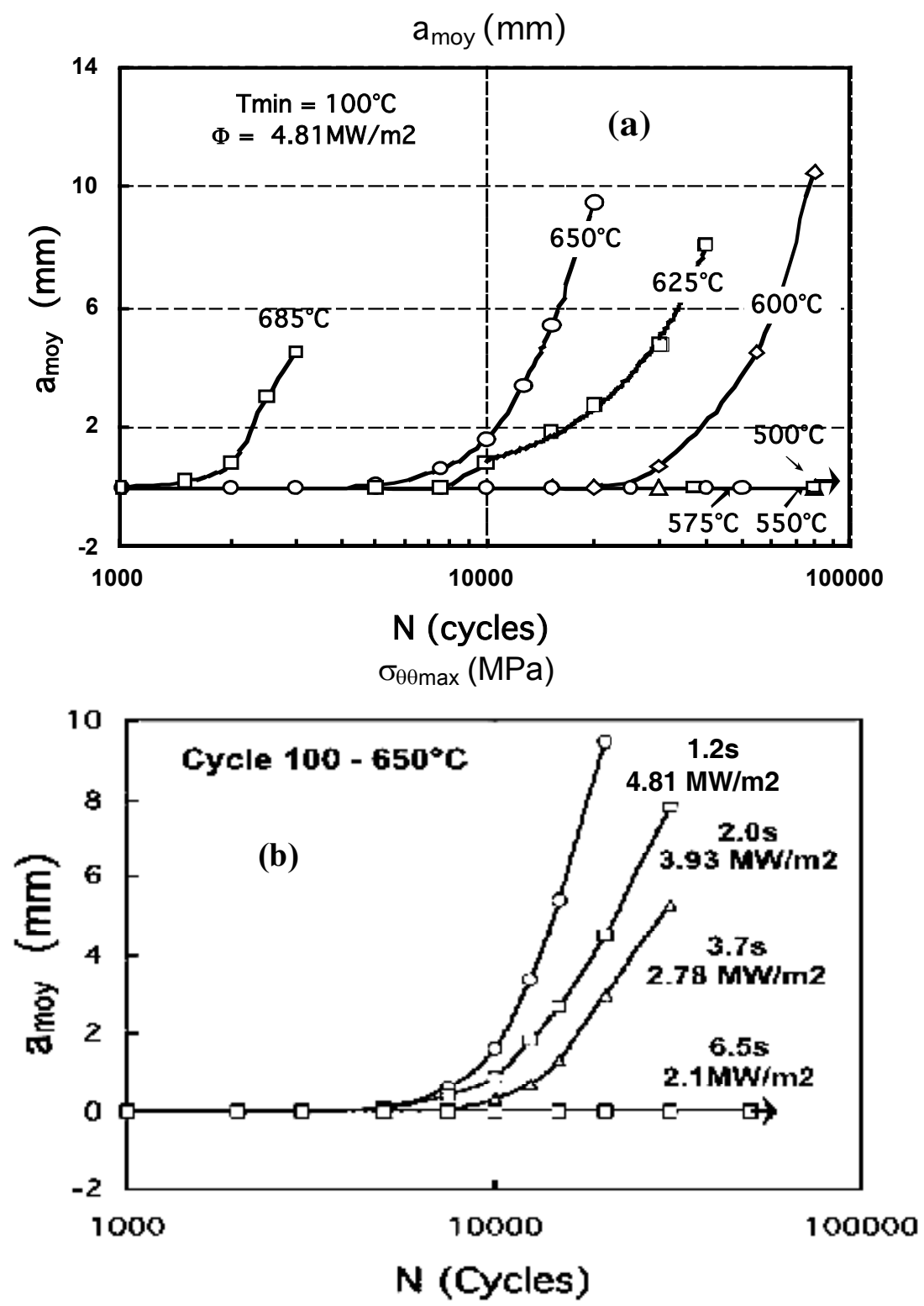

Notes: Effect of (a) $\mathrm{T}_{\max }$ and (b) heating period (or heat flux density $\Phi$ ). 
Figure 10 presents the TF propagation rate as a function of calculating the maximum

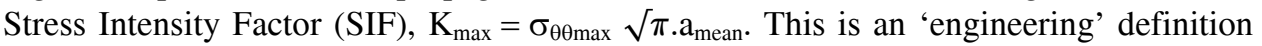
of SIF, since it does not consider multiaxial loading and also $\mathrm{a}_{\text {mean }}$ presents an 'equivalent' crack length. This Paris-type relationship seems to better rationalise the TF crack propagation than mechanical strain intensity factor defined as: $\Delta \mathrm{K}_{\max }=\Delta \varepsilon_{\mathrm{m}} \cdot \sqrt{\pi} \cdot \mathrm{a}_{\text {mean }}$ (Rézaï-Aria et al., 2006; Medjedoub, 2004; Bergström and Rézaï-Aria, 2006).

Figure 10 Thermal fatigue crack propagation rate as a function of the maximum stress intensity factor

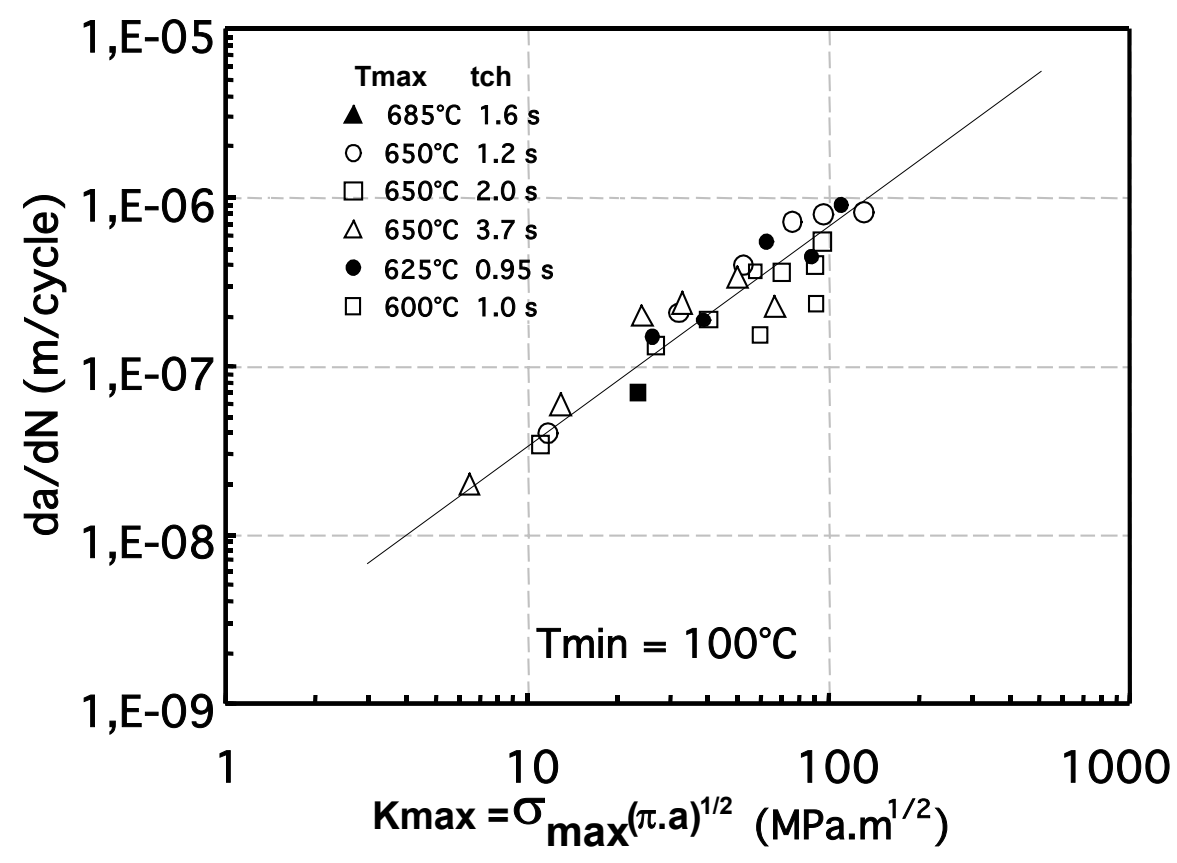

In general, TF resistance rates of tool materials are compared based on a maximum or a mean crack depth achieved under a prescribed number of TF cycles. The maximum temperature is not the only relevant criterion for the TF life prediction, since depending upon thermal gradient and thermal stains and stresses, different life cycles can be achieved. We have defined several fatigue life cycles corresponding to several prescribed surface crack lengths (for example, $0.1 \mathrm{~mm}, 0.3 \mathrm{~mm}$, etc.) (Medjedoub, 2004). Then each $\mathrm{TF}$ life was plotted as a function of $\mathrm{T}_{\max }$ or mechanical parameters such $\Delta \varepsilon_{\mathrm{m}}, \Delta \sigma, \sigma_{\theta \theta \max }$, etc. Figure 11 presents TF life as a function of the $\sigma_{\theta \theta \max }$. Such mechanical approaches are more relevant to the comparison between different material and also between $\mathrm{TF}$ and isothermal LCF (Oudin et al., 2001) or TMF (Le Roux et al., 2006; Engler-Pinto and Rézaï-Aria, 2000) life curves. 
Figure 11 Thermal fatigue life ( $\mathrm{N}$ cycles) as a function of $\sigma_{\theta \theta \max }$

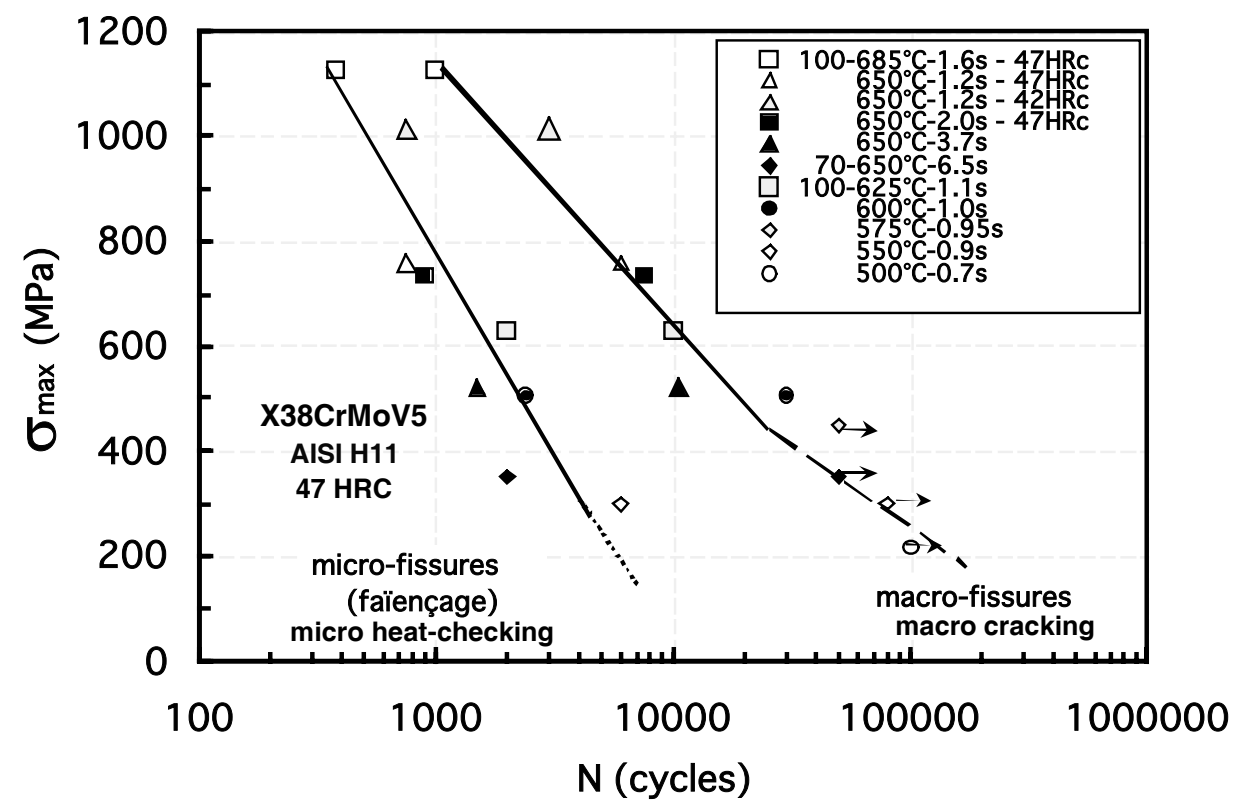

Note: Note that arrows indicate TF experiments are stopped, without any macroscopic cracking.

\section{Conclusions}

The thermal fatigue behaviour of X38CrMoV5 AISI H11 (47HRC) is studied. The effects of the maximum temperature of thermal cycle (from $550^{\circ} \mathrm{C}$ to $685^{\circ} \mathrm{C}$ ) and the heating period (from about 1.2 to $6.5 \mathrm{~s}$ ) are assessed.

The micro- and macroscopic heat-checking cells are formed. The microscopic heat-checking mechanism consists of surface oxide-scales cracking. The depth of such cracking is mainly limited to the thickness of oxide scales. The formation of the micro- and macroscopic heat checking is due to the multiaxial mechanical stress and/or strain loadings that are generated by transient thermal fatigue solicitations.

The evolution of the microscopic heat-checking density versus the number of thermal fatigue cycles shows a sigmoïdal trend and achieves a quasi-asymptotic limit. This stabilised density is very much heating period (or heat flux density)-dependent, while it is quasi-independent on maximum temperature of the thermal cycle. The macroscopic heat-checking network is formed from the microscopic heat-checking.

The thermal fatigue strains and stresses are calculated via numerical simulations using ABAQUS. A Paris-type law relating the mean thermal fatigue crack propagation rate to the maximum stress intensity factor, $\mathrm{K}_{\max }$, could rationalise the thermal fatigue crack propagation resistance of the steel examined under different thermal fatigue test conditions.

It is found that $\sigma_{\max }$ is a relevant criterion for rationalising both the microscopic heat-checking initiation life and the surface macroscopic cracking life. 


\section{Acknowledgements}

The authors from Ecole des Mines d'Albi-Carmaux would like to acknowledge the French Casting Centre (CTIF) for partially supporting these activities. The authors also acknowledge Ing. G. Bocquet and Dr. A. Hamasaiid from the Ecole des Mines d'Albi-Carmaux for their valuable contributions to the heat transfer measurements and analyses on actual dies.

\section{References}

Ahmer, Z., Velay, V., Rézaï-Aria, F. and Bernhart, G. (2006) 'Cyclic behaviour simulation of X38CrMoV5 (AISI H11) tempered martensitic hot work tool steel', 7th International Tooling Conference, Turino, Italy, 2-5 May.

Bergström, J. and Rézaï-Aria, F. (2006) 'High temperature fatigue of tool steels', 7th International Tooling Conference, Turino, Italy, 2-5 May.

Da Silva, C.R.S. and Boccalini, M., Jr. (2005) 'Thermal cracking of multicomponent white cast iron', Materials Science and Technology, May, Vol. 21, No. 5, pp.565-573.

Daffos, C. (2004) 'Endommagement des outillages de forgeage traités par nitruration: Étude et Modélisation', PhD dissertation, Ecole des Mines d'Albi, January.

Dour, G., et al. (2005a) 'Development of a non intrusive heat transfer gauge and its application to high pressure die casting - effect of the process parameters', Journal of Materials Processing Technology, Vol. 169, pp.223-233.

Dour, G., Medjedoub, F., Diaconu, G., Girardin, D., Michrafy, A., Loulou, T. and Rézaï-Aria, F. (2006) 'Size effect in transient thermal fatigue testing and thermo-mechanical screening of coatings', 7th International Tooling Conference, Turino, Italy, 2-5 May.

Dour, G., Medjedoub, F., Le Roux, S., Diaconu, G. and Rézaï-Aria, F. (2005b) 'Rules to design a transient thermal fatigue test using thermal stresses analysis and normalilsed approach', Journal of Thermal Stresses, January, Vol. 28, No. 1, pp.1-16.

Engler-Pinto, C.C., Jr. and Rézaï-Aria, F. (2000) 'Thermo-mechanical fatigue investigations of SRR99', in H. Sehitoglu and H. Maier (Eds.) ASTM-STP 1371, American Society for Testing and Materials, Pennsylvania, pp.150-164.

Jean, S., Le Roux, S., Miquel, B. and Rézaï-Aria, F. (1999) 'An investigation on heat checking of hot work tool steels', Proceedings of the 5th Int. Tooling Conference: Tool Steels in the Next Century, Leoben, Austria, 29 September-1 October.

Le Roux, S., et al. (2006) Unpublished Results, Ecole des Mines d'Albi-Carmaix.

Medjedoub, F. (2004) 'Détermination des paramètres influant sur le phénomène d'endommagement par fatigue thermique des moules en fonderie sous pression d'aluminium', $\mathrm{PhD}$ dissertation, Ecole des Mines d'Albi-Carmaux, May.

Medjedoub, F., Dour, G., Rézaï-Aria, F. and Hairy, P. (2005) 'Endommagement par faïençage des moules de fonderie sous pression en fatigue thermique: origines, mécanismes et approaches', Fondeur et Fonderie d'Aujourd'hui, April, No. 224, pp.22-37.

Medjedoub, F., Dour, G., Lamesle, P., Le Roux, S. and Rézaï-Aria, F. (2008) Modeling of Cyclic Oxidation at Variable Temperature, Application to X38CrMoV5 Tool Steel, Accepted for publication in Oxidation of Metals.

Oudin, A., Lamesle, P., Penazzi, L. and Rézaï-Aria, F. (2001) 'Thermomechanical fatigue behaviour and life assessment of hot work tool steels', Temperature Fatigue Interaction, SF2M, Paris, 29-31 May, pp.195-201.

Rézaï-Aria, F. (2002) 'Thermal fatigue of hot work tool steels', Keynote Paper in 6th International Tooling, Conference, Sweden, 10-13 September.

Rézaï-Aria, F., et al. (2006) Unpublished Results, Ecole des Mines d'Albi. 